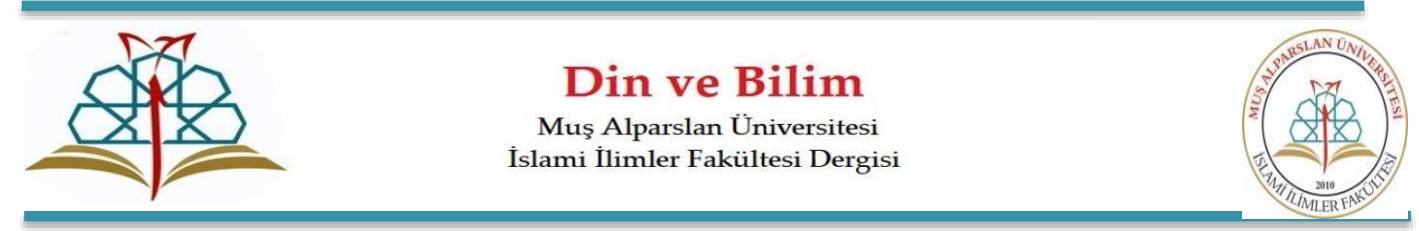

Din ve Bilim - Muş Alparslan Üniversitesi İslami İlimler Fakültesi Dergisi

Region and Science - Journal of Muş Alparslan University Faculty of Islamic Sciences e-ISSN: 2667-7717 Aralık/December 2020, 3(2): 68-82

\title{
Mevlânâ'da Öne Çıkan Bazı Ahlâkî Değerlerin ve Kusurların İşleniş̧i ve Eğitim Açısından Tahlili
}

Processing of Some Moral Values and Defects that Stand out in Mewlana and Analyzing Them from the Point of View of Education

\author{
Hacer ÇETIN \\ Dr., Öğretmen, Milli Eğitim Bakanlığı. \\ PhD., Teacher, Ministry of Education, İstanbul/Turkey \\ hacercetin66@gmail.com \\ ORCID: 0000-0002-2044-7913 \\ Makale Bilgisi I Article Information \\ Makale Türü / Article Type: Araştırma Makalesi / Research Article \\ Geliş Tarihi / Date Received: 14 Ekim / October 2020 \\ Kabul Tarihi / Date Accepted: 14 Aralık / December 2020 \\ Yayın Tarihi / Date Published: 31 Aralık / December 2020 \\ Yayın Sezonu / Pub Date Season: Aralık / December \\ DOI: $10.47145 /$ dinbil.810832
}

Bu çalışma, Marmara Üniversitesi Sosyal Bilimler Enstitüsü’nde Prof. Dr. Ahmet Koç danışmanlığında 2019 yılında tamamladığımız "Mevlâna'da Ahlak Eğitimi" başlıklı doktora tezi esas alınarak hazırlanmıştır./ This article is extracted from my doctorate dissertation entitled "Moral Education in Mevlâna", supervised by Professor Ahmet Koç (Ph.D. Dissertation, Marmara University, Istanbul/Turkey, 2019).

Atıf / Citation: Çetin, Hacer. "Mevlânâ'da Öne Çıkan Bazı Ahlâkî Değerlerin ve Kusurların İşlenişi ve Eğitim Açısından Tahlili / Processing of Some Moral Values and Defects that Stand out in Mewlana and Analyzing Them from the Point of View of Education". Din ve Bilim - Muş Alparslan Üniversitesi İslami İlimler Fakültesi Dergisi 3/2 (Aralık 2020): 68-82. doi: 10.47145/dinbil.810832

İntihal: Bu makale, iThenticate yazılımınca taranmıştır. İntihal tespit edilmemiştir.

Plagiarism: This article has been scanned by iThenticate. No plagiarism detected. web: https://dergipark.org.tr/tr/pub/dinbil I mailto: dinbil@alparslan.edu.tr

Copyright $\odot$ Published by Muş Alparslan Üniversitesi, İslami İlimler Fakültesi / Muş Alparslan University, Faculty of Islamic Sciences, Muş, 49250 Turkey. Bütün hakları saklıdır. / All right reserved. 


\title{
Öz
}

Bu makalede, Mevlânâ'nın Mesnevî adlı eserinde geniş yer verdiği bazı ahlâkî değer ve kusurlar ele alınmıştır. Mevlânâ'nın Mesnevî̀'de anlattığı hikâye ve aktardığı bilgiler incelenerek bu kavramların eğitim süreçlerine dair tespitler yapmak amaçlanmıştır. Bu amaç çerçevesinde Mevlânâ'nın bu kavramlara yüklediği anlam ve işlev tespit edilmeye çalışılmıştır. Bu da, günümüzde yapılan değer eğitimi çalışmalarında, Mevlânâ'nın eğitim örneğinden faydalanma imkânını ve bunun önemini ortaya koymada bir farkındalık oluşturmaya katkı sunacaktır. Mevlânâ ahlâkî değer ve kusurların anlatımını yaptığı eğitim örneğinde kavramların imanla olan ilişkilerini ön plana çıkarmakta ve pratik yönlerine daha fazla yer vermektedir. Mevlânâ, imanı içsel bir unsur olarak en büyük değer olarak algılamakta, değerleri ve kusurları bu içsel unsurun özelliği ve doğruluğu oranında davranışları oluşturan sebepler olarak görmektedir. Ahlâkî değerler ve kusurlar, iman gibi üst bir değerle ilişkileri anlamında önemli ve öncelikli konulardır. Bu sebeple ahlâkî değer ve kusurlara dönük yapılacak her faaliyet önem taşımaktadır. Bu önem sebebiyle makalede Mevlânâ'nın Mesnevî́de geniş yer verdiği bazı ahlâkî değer ve kusurların kazandığı anlam ve işlevler incelenmiştir. Bu değerler sevgi, hoşgörü, sabır olarak tespit edilmiştir. Ahlâkî kusurlar ise yalan, hile, kıskançlk-haset olarak belirlenmiştir. Makalede bu ahlâkî değer ve kusurlara ait tanıtıcı bilgiler aktarılmış ve Mevlânâ'nın bu değerleri öğretirken yüklediği anlamlara yer verilmiştir. Mevlânâ, değerleri ve kusurları pratik yönleriyle ele almış ve onlara dair tanıtıcı zihinsel, duyuşsal ve davranışsal unsurları örneklemiştir. Ahlâkî değerlerin hangi kusurdan koruyucu olduğuna dair vurgular yapmış ve ahlâkî kusurları ortadan kaldırmada doğru değerin teşhisi ve tedavi sürecine dair ipuçları vermiştir.

Anahtar Kelimeler: Eğitim, Ahlâk, Değer, Değer Eğitimi, Mevlânâ.

\begin{abstract}
In this article, some of the moral values and flaws that Mewlânâ has widely included in his work called Mesnevî are discussed. It was aimed to make determinations about the educational processes of these concepts by examining the story and information conveyed by Mewlana in Mesnevî. Within the framework of this purpose, the meaning and function that Mewlana attributed to these concepts were tried to be determined. It was tried to determine the meaning and function that Mewlana imposed on these concepts and in this way it was tried to show the possibility of using the example of Mawlana's education in the value education studies carried out today. In the example of education in which Mawlana describes moral values and defects, he highlights the relationship of concepts with faith and gives more place to practical aspects. He perceives faith as the greatest value as an internal element, and sees values and flaws as the reasons that form the behavior in proportion to this inner elements' characteristics and faithfulness. For this reason, moral values and defects are important and priority issues in terms of their relationship with a higher value, such as faith. According to this reason, every activity aimed at moral values and defects requires seriousness and is important. Concerning this importance, this article examines the meaning and functions gained by some moral values and flaws. These values are defined as love, tolerance and patience. Moral flaws, on the other hand, have been identified as lies, cheat, jealousy-envy. In the article, introductory information about these moral values and defects is conveyed and the meanings that Mawlana uploaded when teaching these values are included. Mawlana addressed values and defects in practical aspects and exemplified the introductory mental, behavioural and affective elements about them. He emphasized the imperfection of moral values and gave presumptions to the process of diagnosing and treating the correct value in eliminating moral defects.
\end{abstract}

Keywords: Education, Moral, Values, Value Education, Mewlana, 


\section{Giriş}

Mevlânâ, Mesnevî adlı eserinde ahlâkî değerler ve kusurlarla ilgili birçok hikâye anlatmaktadır. $\mathrm{Bu}$ hikâyelerde değerlere ait tanıtıcı bilgiler aktarmaktadır. Teorik bağlamda bir tanımlama yapmamakla birlikte bu değerlerin hangi davranış modellerini içermesi gerektiği, hangi düşünce ve duygu yapıları ile görünür hale geldiği ve bireysel ve sosyal yaşam üzerinde hangi etki ve sonuçları ortaya çıkardığına dair açıklamalar yapmaktadır. Bazı ahlâkî değerleri tekrar tekrar gündemine almakta ve bu değerin yokluğu halinde ortaya çıkacak ahlâkî kusurlara işaret etmektedir. Bunları yaparken ahlâkî değerleri ve ahlâkî kusurları temsil eden modeller üzerinden anlatımını yapmakta, muhtemel soruları sormakta ve cevaplamaktadır. Örnek olaylarla muhatabını zihinsel bir tefekküre davet etmekte, ayet ve hadis örnekleri üzerinden değerleri İslâm ahlâkı bağlamında anlamlandırmakta, deliller sunmakta ve onlara Kur'ânî bir bakış açısı ile bakmaktadır. Aynı zamanda psikolojik bağlamda ahlâkî değerlere dönük motivasyon ve ahlâkî kusurlara karşı ise bir nefret duygusu oluşturmaya çalışmaktadır. Ahlâkî değerlerin veya ahlâkî kusurların oluşumunda sosyal çevrenin etkisine dikkat çekmekte ve bu konuda yapılacak eğitime uygun yaşlarda başlamanın ve nasihat almaya hazırbulunuşluk seviyesinin önemine dikkat çekmektedir. Basit örnek olay örgülerinden karmaşık yapıdaki hikâyelere geçiş yapmakta, başladığı bir hikâyeyi yarım bırakarak daha önce anlattığı hikâyeye atıflarda bulunarak onu tamamlayan bir hikâye örgüsü ile devam ederek soyut kavramlara ait somut bir kazanım elde etmeye çalışmaktadır. Bu psikolojik ve metodik unsurları kullanırken de şiirlerden ve çoğunlukla hikâyelerden yararlanmaktadır. Bu makale çerçevesinde yapılan incelemede, Mevlânâ'nın bazı değerlere ve kusurlara daha fazla yer verdiği ve atıfta bulunduğu görülmüştür. Bu değer ve kusurların, iman ve nefs ile ilişkisi üzerinden öncelendiği tespit edilmiştir. Mevlânâ'nın ortaya koyduğu eğitim örneğinde bazı önemli noktaların olduğu görülmüş ve bu noktalara bağlı bazı önerileri sıralamak mümkün olmuştur.

\section{Mevlânâ'ya Göre Kazanılması Gereken Bazı Ahlâkî Değerler}

Ahlâkî değer kazanımı bir eğitim meselesidir. Zira en genel tanımı ile eğitim, toplumun bireylerini kendi yaşantılarına ve bu arada aktarılan bilgilere ve değerlere dayalı olarak, önceden belirlenen doğrultuda değiştirme ve dönüştürme faaliyetidir. ${ }^{1}$ Değer eğitimi süreci de bu dönüşümün ahlâkî değerler üzerine değişimini ve dönüşümünü ifade etmektedir. Bu sebeple İslâm ahlâk eğitimcileri, gelenekten bugüne doğruluk, sevgi, sabır, şükür vb. değerleri ön plana çıkarmış ve canlı tutmuştur. Zira kişinin ahlâkî yapısı, sahip olduğu değer sistemi ve davranış modelleri üzerinden anlaşılmaktadır. Mevlânâ da Mesnevî̀'de İslâm ahlâk eğitim geleneğinin bakışını yansıtmış, kişinin iç ve dış dünyasını değer kazandırma yoluyla şekillendirmeye çalıştı̆̆ı bir eğitim örneği ortaya koymuştur. Bu sebeple Mevlânâ'nın ahlâk eğitiminde ön plana çıkardığı değerleri hangi yönleri ile ele aldığı ve onlara hangi fonksiyonları yüklediği önem arz etmektedir. Makalede, belirtilen önem sebebiyle değerlerin eğitimsel yönlerden yüklendikleri anlam ve işlevlere dair tahliller ve tespitler yapılmıştır. Mevlânâ'nın bu değerler ile vermeye çalıştığı mesajlar tespit edilmiş ve bu değerlerin bireysel ve toplumsal, aynı zamanda da ruhsal ve davranışsal önemi ortaya konulmaya çalışılmıştır. Mesnevî́de sevgi, hoşgörü ve sabrın öncelikli olarak kazandırılmaya çalışılan ahlâkî değerler olduğu görülmüştür.

\subsection{Sevgi}

Temelde kalbe ait bir duygu olan sevgi, İslâmî perspektifte varlığı başlatan bir hareketin kaynağı olarak görülmektedir. Bu mânada sevgi, her hareketin kaynağı, başlangıcın sebebidir denilebilir. Zira İslâm'da gerçekte hiçbir hareketin korku ile başlamayacağı düşüncesi vardır. En başa

\footnotetext{
${ }^{1}$ Ahmet Cevizci, Ĕ̆itim Sözlü̆̆̈̈̈, (İstanbul: Say Yayıncilık, 2010) , 165.

2 Âl-i İmrân, 3/ 31.
} 
dönüldüğ̈̈nde, varlığın temelinde mutlak varlığın bilinmeyi istemesi, irade etmesi ve sevmesi sebebiyle yapılan bir takdir vardır. O halde, âlem içinde her türlü var oluş ve hareket sevgi kaynaklı meydana gelmektedir. ${ }^{3}$ Sevgi, aynı zamanda hayatın hareket ettirici gücüdür. Ayrışmış olanı birleşmeye sevk eden, aidiyet kazandıran, kâmil bir formla kişiler arası ilişkilerde üstünlüğü ortaya çıkaran onkolojik bir gerçekliktir. ${ }^{4} \mathrm{Bu}$ bağlamda sevgiyi anlam ve işlevine uygun anlayan ve anlatan önemli şahsiyetlerden biri Mevlânâ'dır. Zira bu başarısı sebebi ile Mevlânâ, sevgi değeri ile anılan bir düşünür haline gelmiştir. Mevlânâ'da sevgi değeri, önce yaratıcıya dönük güçlü bir nitelik olarak anlaşılmaktadır. Daha sonra bu sevginin genellemesi süreci işletilmektedir. Bu süreç ile sevilenin sahibi olduğu bütün varlıklarla olan ilişkide görünür hale gelen bir sevgi anlayışı geliştirilmektedir. Bu da var olan sevginin gerçek ve anlamlı oluşunun işareti olarak kabul edilmektedir. Mevlânâ, bütün değer sitemini bu özellikteki bir sevgi ile desteklemektedir. Zira Mevlânâ'ya göre diğer bütün değerlerin arzusunu oluşturan duygu sevgi olduğu gibi, bütün değerlerin varlığı da sevgiyi canlı ve gerçek kılmanın imkânını oluşturmaktadır. Sevginin olmadığı bir yerde yaratıcı ile insan arasında kulluk ilişkisinden bahsetmek mümkün görünmemektedir. Zira Mevlânâ'da sevginin hâsıl edeceği kullukta israr ve mücadele ile en nihaî değer olan aşka ulaşılmaktadır. Kullukta ibadet ve iyi işler vesilesi ile bir kazanç, karşlıklı ilişki vardır. Bunun yanı sıra bu ilişkide hiçbir karşlığın beklenmediği, birliği-vahdeti oluşturmaya bir yol vardır. Mevlânâ, bu ilişkiyi; "Kulluk et, belki âşık olursun!" diyerek özetlemiş ve bu bakışını Allah'ın Peygamberi sevgilisi seçmesi ile hikâyelendirmiştir. Sevgi kulluğu, kulluk aşkı, aşk ise vahdeti doğurmaktadır. ${ }^{5}$ Zira kelime anlamı itibari ile de sevgi iki yönlü ve farklı mesajları kapsamaktadır. Sevgi kelimesi bir şey hakkında kullanılır ve başka kasıtlar ile mesajlar taşır. Örneğin Ehabbu'llahe (Allah'ı seviyorum) ifadesi, Allah'a itaati seviyorum anlamı verebilmektedir. Burada Allah'a itaat hususundaki muhabbet, Allah'a muhabbet şeklinde ifade edilmiştir. Bu sevgide muhabbete, merhamete, dostluğa ve ödüle yönelik yönler vardır. Birini sevmek aynı zamanda onun için asla herhangi bir kötülük istenmediği mesajını vermenin biricik yoludur. Bu sebeple Allah, Halil (dost) ve Habib (sevgili) esmaları ile de kulu ile kurduğu ilişkinin temellerine dair mesajlar vermektedir. ${ }^{6}$

O halde kulluk, sevgi temeli üzerine yükselmektedir. Aynı zamanda kâmil bir sevgi, şimdi ve gelecekte Allah ile olmayı ve ona kavuşmayı ifade etmektedir. Bu ise hakiki aşkın temsilidir. Sevginin her türlüsü ise bu gaye için birer vesile ve basamak hükmündedir. Zira ancak bu sevginin kişiyi yaratıcısına yöneltmesi ile insan kemâle ulaşma faaliyeti içinde olabilir. Nitekim kâmil insan örneği olarak Hz. Muhammed ile Allah arasındaki bağın da sevgi temelinde alınışı bu ilişkiye işaret etmektedir. O halde en büyük eğitici olan Allah'ın, kâmil insan modelini ortaya koyan Peygamberine "sevgili" hitabı ve sevgiyi bakış ile davranışa sebep göstermesi, diğer duygularda olduğu gibi sevginin de bir eğitim konusu olduğuna işarettir. Sevginin mekânı kalptir ve sevgi anlamla birlikte kalpte yerleşik hale gelir. Bu sebeple sevgi, ayn zamanda kalp eğitiminin önemli bir unsurudur. ${ }^{7}$ Kalpte yer edinecek sevginin hangi özellikte olması gerektiği, sevginin türleri ve insan için anlamları ve sınırları, sevgiye dair müspet ve menfi haller bu eğitimin birer parçasını oluşturmaktadır.

İnsanın yaratıcısı ve çevresi ile ilk ilişkisi, sevgi üzerinde başlamaktadır. Bu ilişkinin farkındalığı olan imanın özünde de sevgi ve tezahürlerini görmek mümkündür. Kur'ân'da da "İman edenlerin Allah'a olan sevgileri (onlarnkinden) çok daha fazladır"s ifadeleriyle bu ilişkiye işaret edilmektedir. Zira insan faaliyetlerinde değerli olanları ortaya çıkarmaya teşvik edici güçlü duygu, sevgidir. Bu duygu sebebiyle fıtrî sevgi, neslin devamını temin ettiği için değerlidir ve teşvik içerir.

\footnotetext{
3 İbnü'l Arabî, Fusûsü'l Hikem, çev. Ekrem Demirli (İstanbul: Kabalcı Yayıncılık, 1999), 498.

4 Aliye Çınar, Erdemler Felsefesi ve Psikolojisi (Bursa: Emin Yayınları, 2013), 72-73.

5 Şefik Can, Mesnevî Tercümesi (İstanbul: Ötüken Yayınları, 2016), C. V, 228, b. 2725-2735. Bu eser daha sonraki dipnotlarda

Mesnevî olarak verilecektir. Gerek duyulan dipnotlarda beyit numaralarına da yer verilecektir.

${ }^{6}$ Ebû Hilâl El-Askerî, Arap Dilinde ve Kur'ân'da Farklar Sözlü̆̆̈̈̈, 2. Basım ( İstanbul: İşaret Yayınları, 2013 ), 162.

${ }^{7}$ Ahmet Koç, İhvân-ı Safâ'nın Ĕ̆itim Felsefesi (İstanbul: İfav Yayınları, 1999), 160.

8 Bakara, 2/ 165.
} 
Evlat sevgisi koruyup kollama, meşakkatlere katlanma ve terbiye faaliyeti olarak tezahür etmektedir. Sanat eseri ortaya koyma, siyaset ile nizama katkı sunma isteği, ilimler ile nefsi ve ahlâkı tezkiye etme arzusu sevgi ile ortaya çıkan ve anlam kazanan faaliyetlerdir. ${ }^{9}$ Görülmektedir ki yaratıcıya duyulan sevgi, diğer varlıklara duyulacak sevginin sebebi ve temelidir. Allah'a dönük bir sevgi olmadan Yunus'un ifade ettiği "yaratılanı severiz, yaratandan ötürü" ilkesi ile uyumlu evrensel ve işlevsel tam bir sevgi anlayışına ulaşmak mümkün değildir. Bu sebeple Mevlânâ, kişiye yaşadığı zorlukları bile güzel ve anlamlı gösterecek bir sevgi kazandırma gayreti göstermiştir. Zira Mevlânâ'ya göre sevgi bilgi gerektiren, elde edilmesi halinde de kişiyi arif derecesinde övülecek bir makama taşıyacak olan değerdir. Bu yolda kişiye engel olacak davranış modelleri üzerinde de duran Mevlânâ, bu konudaki eğitimin nihaî hedefi olarak da aşka işaret etmektedir. Bu hedefe ulaşabilmede vasıtalara ve sınırlı sevgi alanlarına dikkat çeken Mevlânâ, eğitimden uzak bireyde dünya sevgisine dair oluşacak aşırılığın, insanı hakikatlerden ve özünden koparan etkisine vurgu yapmaktadır. Sevginin bilinebilir ve uygulanabilir bir duygu olduğunu belirtmektedir. Sevginin görünür bir duygu olduğunu, aksi halde gerçek varlığa sahip olmayacağını ifade etmektedir. Yaşanan zorlukları, sevginin hakikatini açığa çıkarmada ve eksiklikleri göstermede vesileler olarak görmektedir. ${ }^{10}$ Mevlânâ, aynı şekilde sevginin iyileştirici yönüne dikkat çekmektedir. Sevginin bireysel ve toplumsal faydaları konusunda, muhatabını bilgilendirmekte ve bu değeri edinmeye dönük güçlü sebepleri şöyle sunmaktadır:

Sevgi ile tortular durulur, arınır. Sevgiden dertler şifa bulur, sağlığa kavuşur. Sevgide ölü dirilir, sevgi yüzünden padişah kul olur. Sevgiden hapishane, zindan gül bahçesi olur. Sevgi yüzünden karanlık evler aydınlanır, nurlanır. Sevgi yüzünden dikenler suzan olur. Sevgi yüzünden nar nur olur. Sevgiden dev huri kesilir. Sevgiden kederler, üzüntüler neşe olur, sevinç olur. Sevgi yüzünden yol azdıran "gul" yol gösterici olur, hidayete yol açar. Sevgi yüzünden hastalık, sıhhat ve afiyete çevrilir. Sevgiden kahr rahmet olur. ${ }^{11}$

Mevlânâ'nın sevginin iç ve dış dünyayı şekillendirici, değiştirici gücüne dikkat çektiği görülmektedir. Zira Mevlânâ'ya göre sevgi, öncelikle kişiyi yaratıcısına karşı şekillendirir, dönüştürür ve kul olma makamına yükseltir. Bu bağ yaratıcının kulu, kulun yaratıcıyı sevdiği ilâhî aşk için önemli bir basamaktır. ${ }^{12} \mathrm{Bu}$ aşamadan sonra her şey başka bir boyut ve anlam kazanır. Topraktan yaratılan insan, bu sevgiyle âli işler ve hisler için yüceliğe doğru bir oluş içine girmektedir. ${ }^{13} \mathrm{Bu}$ oluş, kişinin yaratıcısı ile yakınlığına, iç dünyasına, diğer insanlar ile ilişkisine, yaşadığı çevreye kadar her şeyi içine alan bir devinim halidir.

Görülmektedir ki Mevlânâ, imanın amel ile görünür olmaya başladığı gibi, derin ve sağlam bir psikolojik temsilin de ancak çok yönlü faziletlere ulaştıran sevgi değeri ile görünür olabileceğine işaret etmektedir. Mesnevî́de bütün ârizî kusurların, ruhsal hastalıkların kaynağı olarak sevginin yokluğu fikri canlı tutulmuş ve neredeyse her hikâye veya konunun bir parçası olarak sevgi, aşk kavramına bakan bir yöne atıf yapılmıştır. Bu yönü ile bakıldığında Mevlânâ'da bir değer olarak sevgi, bireysel ve toplumsal yaşam için lokomotif görevi görmekte ve insan yaşamına kutsallık katan bir değer olması sebebiyle, eğitimsel bir önem taşımaktadır. Bütün değerlerin kazanımına teşvik oluşturmada, zihinsel, duyuşsal ve davranışsal bakımdan iyi oluşu, anlamlı ve değerli görmeyi, lezzet almayı sağlayan bir bilişin imkânıdır. Sevgi değeri, bir yerdeki olumlu değişimin ve dönüşümün ilk basamaklarını ortaya çıkarmada itici bir güç olarak da öncelenmesi gereken değerlerden biridir. Diğer yandan sevgi, yaşamın zorlukları karşısında umudu canlı tutmakta ve yaşamı iyi yönleri üzerinden anlamlandırmayı sağlayan güçlü bir psikolojik duruşu mümkün kılmaktadır. Mevlânâ, sevgi değerini işlerken özellikle yaratıcı ile kul arasındaki ilişkiyi hikâyeleştirmekte, örnek olaylar üzerinden sevginin kazanımı halinde ortaya çıkabilecek düşünce, duygu ve davranış modellerinin neler

\footnotetext{
${ }^{9}$ İhvân'1 Safâ, Resâilü İhvâni's Safâ ve Hullâni'l Vefâ, C.4, (Beyrut: Daru Sadır, 1974), 278-279.

${ }^{10}$ Mesnevî, C. II, 134, b.1530.

${ }^{11}$ Mesnevî, C. II, 135, b.1530-1535.

${ }^{12}$ Mesnevî, C. IV, 223-224, b. 2921-2925.

${ }^{13}$ Bayraktar Bayraklı, Kur'ân'da Değ̌işim, Gelişim ve Kalite Kavramları (İstanbul: İfav Yayınları, 1999), 235.
} 
olabileceğinin tanıtıcı bilgisini vermektedir. Bu da gerçek anlamda sevginin bir değer olarak neyi ifade ettiğinin bilgisini kazanmayı mümkün kılmaktadır. Aynı zamanda sevgi; yaratıcı, diğer varlıklar ve içinde yaşanılan dünya ile ilişkinin kazanımlarına ve dönüşümüne dair bir bilinç oluşturarak şahsiyetin inşa edilişinde zengin bir biliş sunacaktır.

\subsection{Hoşgörü}

Sözlükte "kolaylık göstermek, yumuşak davranmak, hatayı görmezlikten gelmek" anlamındaki müsâmaha, "smh" şeklindeki aynı kökten gelen "tesâmuh" ve "semâha" ile birlikte kullanılan, ahlâk terimi olarak insanlara yükümlülükler konusunda kolaylık göstermeyi, toplumsal yapıyı sarsıcı mahiyette olmayan hata ve kusurları hoş görmeyi, çeşitli düşünce, inanç ve davranışları özgürce dile getirmeyi ifade eden bir değerdir. Günümüz Arapçasında müsamaha yerine daha çok "tesâmuh" ve "semâha", Türkçede ise "hoşgörü" kelimeleri kullanılmaktadır. ${ }^{14}$ Konu ile ilgili ayet ve hadislere bakıldığında "silm", "sulh", "lin (yumuşaklık)", "hilm" gibi kelimeler ile İslâm'ın temel ilkelerine bağlı kalmak kaydıyla diğer insanların kişiliklerine, düşünce ve inançlarına saygı duyma ve istenmeyen durumları iyilikler üzerinden çözümlemenin tavsiye edildiği görülmektedir. ${ }^{15}$ İnsan yaratılış özelliği itibari ile hata yapabilen bir varlıktır. Bu özelliği, insanın hatadan korunamayacağı anlamında değildir. İnsan kendisinin ve diğer insanların kusurları ile karşı karşıya kalabilmektedir. İslâm ahlâk eğitiminde, kişinin kendi kusurları veya başkalarının kusurları karşısında yapıcı bir rol üstlenebilmesinde hoşgörü gibi bir değer öncelenmiştir. Zira insan olmak, kutsal bir değer taşımaktadır. İnsanın değerini koruyabilmesi için özverili çabalara ihtiyacı vardır. Eğitim, bu konuda ortaya konulan çabaların en değerlisini oluşturmaktadır. Bu eğitimin gücü ise insanın kendisinin ve başkalarının haklarına karşı bir bilinç ve anlayış geliştirmesi ile doğru orantılıdır. ${ }^{16}$

Hoş görme ve görülme kültürü, yaratıcı ile insan ilişkisinin temelinde vardır. ${ }^{17} \mathrm{O}$ halde insan için bu değer, varoluşsal bir anlam taşımaktadır. Zira tövbesini sayısız defa bozan bir kula, yöneldiği ilâhî kapıdan her zaman bir hoşgörü ve kabul vadedilmiştir. ${ }^{18}$ Bu aynı zamanda Kur'ân'î ve Peygamberî bir yaklaşım örneğidir. ${ }^{19}$ Zira tövbe, aynı zamanda hoş görülmek isteyen kişiye güçlü bir şekilde hoş görmesi gerektiği farkındalığı kazandırmakta ve "hoş gör ki hoş görülesin" 20 ilkesinin kazanımını ifade etmektedir.

Mevlânâ'da hoşgörü, onarıcı psikolojik bir faaliyet olarak anlaşılmaktadır. Zira Mevlânâ'ya göre hoşgörü kültüründen uzaklaşma, kınama alışkanlığını oluşturmaktadır. Kınama ise kişinin kendi menfaat ve bakış açısından kaynaklanan bir haldir. Bu yönüyle kınama, zan ve hayallere dayalı bir bakışı simgelemektedir. Mevlânâ, bu bakış ile temsil edilen durumun imana/inanca zarar vereceğini savunmaktadır. Bu bakışın gerek iç gerekse dış dünyada vehimleri, düşünce ve hayalleri ortaya çıkaran psikolojik ve ahlâkî çöküşü hazırlayacağına dikkat çekmektedir. Mevlânâ'ya göre kınama faaliyeti içerisinde olan bireyde, şahsiyet oluşmamış ve gelişmemiştir. Bu sebeple kınama alışkanlığını

\footnotetext{
${ }^{14}$ Mustafa Çağrıcı, “Müsamaha”, DİA, 2006. Erişim tarihi: 29.11.2020.

15 Lokman , 31/18-19; Bakara, 2/44; Fussilet, 41/34.

${ }^{16}$ Kemal Çakmaklı, Koruyucu Ruh Sağlı̆̆ı (İstanbul: Seha Yayınları, 1997), 56-57.

17 Al-i İmran, 3/155; Nisa, 4/99-149-153

18 "Gel, gel ne olursan ol yine gel; ister kâfir, ister mecusi, ister puta tapan ol yine gel! Bizim dergâhımız ümitsizlik dergâhı değildir; Yüz kere tövbeni bozsan da yine gel!" hitabı Mevlânâ'ya atfedilmektedir. Fakat daha sonra yapılan araştırmalarda bu mısraların Orta Asyalı ünlü sufî Ebu Said-i Ebu'l-Hayr'a ait olduğu iddialarına yer verilmiştir. Fakat bu beyitlerin Mevlânâ'nın bakışına aykırı bir mâna taşımadığını söylemek mümkündür. Nuri Şimşekler ve Esin Çelebî, Mevlânâ'dan Mevla'ya Ulaşanlar (Konya: Bahçıvanlar Matbaa, 2012),51.

19 "Ey kavmim! Rabbinizden bağışlanma dileyin, sonra da tövbe edin ki, üzerinize bol bol yağmur göndersin ve gücünüze güç katsın. Günahkârlar olarak yüz çevirmeyin." bk. Hûd, 11/ 52-61-90; Nahl , 16/ 119; İsrâ,17/ 25 vd. Ebü Bekri's-Siddık (r.a) anlatıor: "Resulullah (a.s) buyurdular ki: "İstiğfar eden kimse günde yetmiş kere de tevbesinden dönse günahta masum sayılmaz." Hadisler için bk. Ebû Dâvûd es-Sicistânî, Sünen, hzl. Necati Yenial ve Hüseyin Kayapınar, C.6 (İstanbul, Şamil Yayınları,1987) Salat, 1514.

20 Salih bin Ahmet bin Hanbel, çev. Hüseyin Yıldız, Zekeriya Yıldız, Hasan Yıldız, C.I (İstanbul: Ocak Yayınları,2013) Müsned, 249 .
} 
tezkiye etmek ahlâkî, bireysel, toplumsal ilerleme ve gelişme için de bir ihtiyaçtır. Mevlânâ, Mesnevî'de bu bakışı yansıtan bir hoşgörü algısı ve kültürü oluşturmak için farklı farklı hikâyelerle konuyu ele almaktadır. Mevlânâ'ya göre kınama kültürünün yukarıda bahsedilen bireysel etkilerinin yanında toplumsal etkileri de vardır. ${ }^{21}$ Mevlânâ, bu kültürün bir toplum içerisinde eleştirilme ve toplumsal baskı endişesi doğurabileceğini ifade etmektedir. Bu durumda bireysel gelişimin aksayacağını ve toplumsal kabul görme gayretinin ortaya çıkacağını savunmaktadır. Mevlânâ, bu durumu psikolojik ve ahlâkî baskının bir ürünü olarak, asli sorumluluklarda ihmalin ortaya çıkmasının sebebi olarak görmektedir. Bu da Mevlânâ'ya göre vazife kültüründen uzaklaşma anlamı taşımakta; tutarsız ve çok yapılı kişiliklerin ortaya çıkmasına zemin hazırlamaktadır.22 Mevlânâ için bu süreç bireyler arasında halis, geliştirici, olumlu eleştiri kültürünün oluşumunu da engellemektedir. Çünkü toplumsal kınamalara maruz kalan birey, bu baskıdan kurtulamadığ 1 takdirde şiddet eğilimi içine girebilmekte, kendini kabul ettirmeye dönük davranışlar sergilemektedir. Bütün çabalarına rağmen bütünleşemediği toplum, onun gözünde değersizleşmekte ve sonuç itibariyle bir kopuş yaşanmaktadır..$^{23}$

Hoşgörü zemininin korunamadığ kimlik sorunu ortaya çıkmaktadır. Mevlânâ'nın Mesnevî̀'de sık sık bu soruna işaret eden konulara yer verdiği görülmektedir. Bu konularda benlik sorunu ile öz denetimini yapamayan bireye, kimlik sorunu ile birbirini tanıyamayan bireylerin olduğu bir topluma işaret etmektedir. Mevlânâ, bu iki sorunun, kişiyi yoldan çıkaran ve değerlerine aykırı unsurlarla mücadeleden alıkoyan yönlerine dikkat çekmektedir. Mesnevî'de bu kişiler için ortaya çıkacak olası beklenti ve hayallere yer vermektedir. ${ }^{24}$ Mevlânâ'ya göre bu durum ise, kurban psikolojisi ile hareket eden edilgen bireylerin sayısını artırmaktadır. Bu sonuca işaret eden Mevlânâ: "Allah aşkı için çalış, Allah aşkı için hizmette bulun; halkın kabul etmesi ile reddetmesi ile ne işin var?" 25 sorusu ile kişiyi benlik ve kimlik kazanacağ hakiki uğraşlara davet etmektedir. Bu tablo, kimlik ve kişiliğe kaynaklık edecek, hoşgörü kültürünü kazandıracak, içsel ve dışsal bir bütünleşmeye imkân verecek bir değer eğitimi ihtiyacının varlığını göstermektedir. Mevlânâ, bu ihtiyaca cevap verecek, güçlü bir farkındalık oluşturacak bir eğitim örneği ortaya koymakta ve insanların kınaması karşısında benlik ve kimliğini geliştirmeye odaklanmış kişi örneğinin hedeflenmesi gerekliliğini savunmaktadır. ${ }^{26}$ Mevlânâ, burada yaratıcının normlarına yüklenmesi gereken kutsallığın, toplumun normlarına yüklendiği yanılgısına işaret etmekte ve bu yanılgıya düşmemek için kınama kültürü karşısında gelişim faaliyetlerine teşvik etmektedir.

Mevlânâ, kınama kültürünün insan ilişkilerinde diğerini sevme, benimseme ve olgun ilişkiler kurabilmede bir pranga görevi üstlendiğine dikkat çekmektedir. Kınama kültürünün hâkim olmasını, bireysel ve toplumsal gelişmelerin sekteye uğradığ 1 durumlar olarak görmektedir. ${ }^{27} \mathrm{Bu}$ sebeple Mevlânâ, gerçekleştirdiği eğitim faaliyeti ile kınama kültürüne karşı güçlü bir irade oluşturmak istemektedir. $\mathrm{Bu}$ iradenin elde edilmesine yönelik bir arzu oluşturmayı amaçlamaktadır.28 Mevlânâ'da, "Kim bu dünyada bir kulun ayıbını örterse, Allah da onun ayıbını kıyamette örter", " Hoş gör ki hoş görülesin" 29 ögütlerinin işaret ettiği kültürel zemin, hem bireysel hem de toplumsal bir ihtiyaç olarak algılanmaktadır. Buradaki önemi ve işlevi sebebiyle Mevlânâ, hoşgörü değerinin kazanımını öncelemektedir.

\footnotetext{
${ }^{21}$ Mesnevî, C. VI, 25.

22 Mesnevî, C. I, 212, b. 3245.

${ }^{23}$ Mesnevî, C. III, 140-145, b. 1522- 1600.

${ }^{24}$ Hayati Hökelekli, Değerler Psikolojisi ve Eğitim (İstanbul, Timaş Yay, 2011), 40.

${ }^{25}$ Mesnevî, C. VI, 71, b. 845.

${ }^{26}$ Mesnevî, C. II, 42, b. 410-415.

27 Mesnevî, C.I, 212, b. 3240.

28 Mesnevî, C. III, 140, b. 1515-1520.

${ }^{29}$ Hanbel, Müsned, 6- 145.
} 


\subsection{Sabir}

Sabır, Mesnevî́ de sık sık anılan değerlerden biridir. Mevlânâ, farklı bölümlerde ve konularda sabrın nasıl ve niçin olması gerektiğine dikkat çekmektedir. Bu konu ile ilgili ayet ve hadislere atıflar yapmakta, Allah sevgisi ve rızasına ulaşmış kişinin vasfı olarak darlıkta, insanlarla ilişkide, ibadetlere devam hususunda sabırlı olmayı teşvik etmektedir. Âl-i İmrân Sûresi'nin 200. ayetinde "Sabrediniz" hitabını elde edilecek mükâfata vurgu yaparak şöyle açıklamaktadır: "Ey Hakk yolcusu, sen de sabretmek zahmetine düşmedikçe, o zahmete katlanmadıkça, karşılığında bir hayır ve mükâfat elde edemezsin. Ne hoştur o şart ne güzeldir o gönüller açan, canlara can katan karşılık." 30 Görülmektedir ki Mevlânâ, sabrın zorluk içindeki lütuflara vesile olan yönüne dikkat çekmektedir. Zira Mevlânâ'ya göre sabır, Allah'ın "hilm" sıfatı ile de ilişkili bir değerdir. Hilm; yapılan hatalara, cezalandırma imkânına rağmen terbiye amaçlı kalpte merhamet ve rahmeti işler hale getirmektir. ${ }^{31} \mathrm{Hilm}$, bu mânada yaratıcının sıfatı olarak Kur'ân'da anılmaktadır. Bununla birlikte hilm, kulun da öfkesini kontrol etmesinde ihtiyaç duyacağı bir değer olarak değerlidir. ${ }^{32} \mathrm{Bu}$ değere atıfla Mevlânâ, sabrın hilmi ortaya çıaracağına ve hilm ile muamele görmeye vesile olacağına işaret etmektedir. Mevlânâ, sabra ulaşılması zor olmayan, içerdiği güzellikler sebebiyle arzulanması gereken bir değer bakışı ile bakmaktadır. Güçlü bir irade ve kararlılık duygusuna sahip olmayı, sabırla mümkün görmektedir. Sabrın kişiye bireysel anlamlar ve tecrübeler sunmasının yanında, nefste iradeye uygun hadiseler yaşama imkânı oluşturmasına da dikkat çekmektedir. ${ }^{33}$

Sabır, ahlâk eğitiminde öne çıkan ve İslâm ahlâk anlayışında üstünlük tanınan en önemli değerlerden biridir. Zira sabrın hem sosyal ilişkilerde hem de inanç dünyasında önemli karşılığı vardır. Dünya zorlukları ile baş etmede bir kalkan olarak kişiyi gücüne odaklanmaya çağıran sabır, her koşulda mâkul kalabilmeyi, isyana kapılmadan sahip olduğu değerleri korumaya alabilmenin teminatıdır. ${ }^{34}$ Zira bu yönüyle bakıldığında sabrı helal ve haramlar karşısında, hayatın zorlukları, acıları gibi insanî hal ve durumlar karşısında bir ihtiyaç olarak görmek mümkündür. Çünkü yaşam kişi için bir imtihan alanıdır ve kozmik acılar, sıkıntılar barındırmaktadır. Mevlânâ, bu sebeple sabır değerini bu dünyanın çetin imtihan ve zorluklarını aşmada bir ihtiyaç olarak görmektedir. Bu imtihan alanındaki en büyük ahlâkî değer kuşkusuz iman-inançtır. Mevlânâ'ya göre iman birey için zorlukları, imtihanları anlamlı hale getirmekte ve bütün zorluklara rağmen inançlı bireyi üstün bir ahlâka taşıyacak, merhamete ulaştıracak imkânlar sunmaktadır. Mevlânâ, bütün yaşamsal kaygı, korku ve zorluklara rağmen bu imanın varlığına işaret eden bazı hal ve tavırlar olduğunu ifade etmektedir. Bu hal ve tavırları ortaya çıkarmada ise bazı değerlerin öncelenmesi gerektiğini savunmaktadır. Bu konuda sabır değerini daha aktif bir değer olarak görmektedir. ${ }^{35}$ Sabır, iman ve hayatın zorlukları arasındaki ilişkiye dikkat çekmektedir. Sabır değerinin psikolojik sağlı̆̆ın korunmasındaki fonksiyonunu da göz önünde bulundurmaktadır. Sabrı kişi için anlamı, ihtiyacı, önemi, kazanımları ve çok yönlü etki alanı üzerinden Mesnevî’nin farklı bölümlerinde ele almaktadır. Örneğin psikolojik anlamda sabrı: "Gamdan kurtulmak için bir anahtar" olarak görmektedir. Devamında muhatabına bu ifade ile neyi anlatmak istediğini şöyle açıklamaktadır: "Eğer tamamıyla zorluklara daldınsa, daralıp kaldınsa sabret. Çünkü sabır, rahatlığın, genişliğin anahtarıdır. Düşüncelerden sakın, canındaki gücü seyret." 36

Sabrı, insan tabiatına aykırı olan zaruri hallere uymak ve karşı koymak olarak kapsamlı şekilde anlamak mümkündür. ${ }^{37}$ Aynı zamanda sabır, kötü bir şey ile karşılaşmaması için nefsin zapt

\footnotetext{
${ }^{30}$ Mesnevî, C. V, 59, b. 584.

${ }^{31}$ Bayraklı, 76.

32 Âl-i İmrân, 3/ 155; Tevbe, 9/ 114.

${ }^{33}$ Mesnevî, C. III, 28, b. 210.

34 Yusuf Ziya İnan, İslâm Ahlâkının İçeriği, C.I (İstanbul: Yaylacık Yayınları, 1992), 71.

35 Mesnevî, C. V, 59.

${ }^{36}$ Mesnevî, C. I, 186, b. 2910.

${ }^{37}$ Ahmet Hamdi Akseki, Ahlâk Dersleri (Ankara: Dib Yayınları, 2016), 171.
} 
edilmesine, güçlükler karşısında üzülmekten kendini alıkoymasına karşılık gelen bir kavramdır. ${ }^{38} \mathrm{Bu}$ anlamları üzerinden bakıldığında sabır, ahlâkîliğin ve inancın önemli bir bölümüne karşılık gelmektedir. Bu yönüyle ahlâk eğitiminde kazandırılacak değerler arasında, aktifliği ve eylemi en çok gerekli kılan değerdir. Fakat İslâmî bakışa atfedilen yorumlara bakıldığında, sabrın bu hakikatlerine aykırı algılar ile karşılaşmak mümkündür. Bu yorum ve algıların, yaşanan zorluk ve sorunlar karşısında hareketsiz kalmayı, zillet ve meskenete bürünmeyi sabır olarak telakki eden bir yanlışlık taşıdığı görülmektedir. ${ }^{39}$ Oysa genel anlamda ahlâk eğitimcileri, özel anlamda Mevlânâ, sabır değerini kazanabilmede hareketliliğe ve çabaya dikkat çekmektedirler. Bu anlamda Mevlânâ sabrı, zorluklar karşısında zaruretlere mahkûm olmamak için tahammül içinde olma, şikâyet etme yerine üretme ve çözmeye odaklanma faaliyeti olarak kabul etmektedir. Bununla birlikte Mevlâna, sabrı zevkin anahtarı, şüphelere karşı bir hazine, her türlü derde karşı savunma ve çözüm imkânı olarak görmekte; bataklıktaki birine el uzatarak onu kurtarma faaliyetine benzetmektedir. ${ }^{40}$

Mevlânâ'ya göre sabır değeri ile kanaat değeri arasında yakın bir ilişki vardır. ${ }^{41}$ Sabır kanaati gerektirirken kanaat da sabrı besleyen ve devamını sağlayan bir değerdir. Bu iki değer arasındaki ilişki, sabrın kişide yerleşik hale gelmesini ve kişi üzerinde belirleyici olmasını sağlamaktadır. Çünkü bu değer, kişinin hayatına dair çok yönlü etki alanı olan bir değerdir. Ahlâkta yerleştirilmesi halinde birçok işleve sahip olacağ gibi, birçok sorunun çözümüne de imkân verecek niteliktedir. ${ }^{42}$

Mevlânâ, sabrın ihtiyatlı davranmayı kapsadığına işaret etmektedir. Bu da zorluklar, sıkıntılar, üzüntü ve keder halinde yanlış karar alma ihtimalini azaltmaktadır. Zira Mevlânâ'ya göre bu zor süreçlerde öfke, keder ve çaresizlik ortaya çıkmaktadır. Sabır, kişiye bu hallerin geçeceğine dair ümit sunarken, duyguları kontrol altına almayı, temkinli davranmayı telkin etmektedir. Bu sebeple Mevlânâ, Mesnevî'de sabrın kazanımları konusuna geniş yer vermektedir. ${ }^{43}$ Mevlânâ'da sabır değeri o an görülemeyen, olayların yönünü değiştirecek sırları keşfetmeye imkân vermektedir. Mevlânâ, kazanımları üzerinden kişide, sabra karşı güçlü bir teşvik oluşturmak istemektedir.

Mevlânâ, zorluklardan kurtuluş ve uhrevî mükâfatları elde etme imkânı üzerinden bir sabır anlayışı oluşturmaya çalışmaktadır. Mevlânâ, sabır değerini kazandırmaya dönük yaptığı eğitimde sabır gerektiren farklı cihetlere dikkat çekmektedir. Dünya nimetlerine ve zorluklarına, nefsanî isteklere, ibadet ve itaatte devamlılığın engellerine, aile içi ilişkilerde yaşanan sorunlara, toplumsal eleştirilere, eğitim faaliyetlerinin güçlüğüne, kötü davranış ve hallere, günahlardan kaçınmanın zorluğuna karşı birçok cihet üzerinden sabrı ele almakta; bu değerin zorluklar karşısında lütuflar doğurduğuna ve kişiyi kazançlı hale getiren davranış örnekleri sunduğuna dikkat çekmektedir. Mevlânâ'da sabır kavramı, pasif bir duruşun aksine aktif bir hal olarak görülmektedir. Sabır, kişi için bu çok yönlü kazanımları sebebiyle Mesnevî'de geniş yer tutmaktadır. O halde sabrın alanları, sabrın işlevsel olduğu duygu ve düşünce örnekleri, dünyevi ve uhrevi kazanımları, bu değerin kazanımını hedefleyen bir eğitim faaliyetinde yer verilmesi gereken alanları ifade etmektedir.

\section{Mevlânâ'ya Göre Sakınılması Gereken Bazı Ahlâkî Kusurlar}

İslâm ahlâk eğitimi; yalan, hırsızlık, kıskançlık, kibir gibi birçok davranışı ahlâkî açıdan bir rezilet olarak görmektedir. İslâm ahlâk eğitiminde değer eğitimi, bu vasıflara karşı koruyucu, kusurları kontrol altında tutmaya imkân veren güzel ahlâk vasıflarını yerleştirme faaliyeti olarak görülmektedir. Bu faaliyetin sağlıkla yürütülmesi için ise onları ortaya çıkaran psikolojik ve sosyolojik

\footnotetext{
38 El-Askerî, 292-293.

${ }^{39}$ Akseki, 172

${ }^{40}$ RA. Nicholson, The Matnawi of Jalaluddin R̂̂mî I-II (Lahore: İslâmîc Book Service, 1989), 9.

${ }^{41}$ Burada sıklıkla "Bir kimse de sabır yoksa onda sağlam bir iman da yoktur." Hadis-i şerifine işaret edilmektedir. bk. Mesnevî, C. II, 56, b. 590-595-600.

42 Mesnevî, C. VI, 120-121, b. 1405-1417-2040-2041.

${ }^{43}$ Mesnevî, C. II, 249-250, b. 3145.
} 
koşulları iyi tahlil etmek gerekmektedir. Bu nedenle burada, Mevlânâ'nın Mesnevî́de yoğunlukla konu edindiği kusurlardan birkaç örneğin anlamı ve içeriğine dair tahliller yapılmaya çalışılacaktır.

Mevlânâ, ahlâk eğitim sistemi içerisinde fazilet kabul edilen değerler kadar değerleri ortadan kaldıracak kusurlar üzerinde de durmaktadır. Zira ahlâk eğitimi sistematik bir yapı içermektedir. Bu sistematik yapı, ahlâkî değer ve kusurlarda daha da belirginleşmektedir. Örneğin doğruluk değerine sahip bir kişi ahlâkî yön itibariyle yalan, hile gibi kusurlu hallere karşı korunmaktadır. Yalan ve hilenin ortaya çıktığı durumlarda ise orada doğruluk değerini yerleştirmek üzere bir terbiye sürecinin takip edilmesi gerekliliği ortaya çıkmaktadır. Bu durum tıp ilmine kıyasla teşhis ve tedavi sürecine tekabül etmektedir. Tedavide en önemli iki unsur doğru teşhis ve soruna uygun, anlamlı çabaları ifade eden doğru tedavidir. Bu sebeple makalenin bu bölümünde birkaç ahlâkî kusur ele alınmış ve terbiye sürecinde bu kusurların fonksiyonlarına dair bir değerlendirme yapılmıştır. Bu kusurlar iman ve nefsle ilişkileri bağlamında öncelenen yalan, hile ve hasettir.

\subsection{Yalan}

Gerçeğe aykırı beyanda bulunmak olan yalan, şayet güçlü bir irâdî süreçle kontrol altına alınmaz ise kişide alışkanlığa dönüşmektedir. İnanç ve ahlâk, doğruluk üzerine kurulduğu gibi yalan ile de yıkılmakta, yok olmaktadır. Bu yönü ile yalan, kişi için büyük tehlike içermektedir. Yalan, hem iç âlemde hem de dış âlemde bir takım yıkıcı sonuçlar ortaya çıarmaktadır. Bu kusurdan korunabilmede rol modeller büyük sorumluluk taşımaktadır. Zira öz itibari ile bakıldığında çocukluk devresi yalandan uzaktır. Fakat yanlış bilgi aktarımı ve rol modellerin örnekliği, bu kusuru ortaya çıkarmaktadır. Devamında ise eğitimin kişiye bu konuda bir irade kazandıramaması, doğruluğu yerleştirmede yetersiz kalması, bu kusuru kalıcı hale getirmektedir. Kişi birçok sebeple yalana başvurabilir. Övülme, ilgi çekme, cezadan kaçınma, alay edilme ve kınanma, menfaat elde etme bu sebeplerden bazılarıdır. ${ }^{44}$ Görülmektedir ki yalanın ortaya çıkışında duyguların önemli bir etkisi vardır. Mevlânâ da bu etkiye işaret ederek, yalan ve doğru kavramını duygularla analiz etmektedir. Kişiyi yalana iten temel duyguları ise güvensizlik ve şüphe olarak görmektedir. ${ }^{45} \mathrm{Bu}$ minvalde Mevlânâ, doğruluğu kişiyi yüceltici bir vasıf olarak övmektedir. Buna karşılık yalanın ise ilâhî takdir sebebiyle gizli kalmayacağına ve kişiyi küçük düşüreceğine inanmaktadır. ${ }^{46}$

Mevlânâ, değer konusunu teşvik yöntemi ile ele almakta ve bilgilendirici, motive edici bir yaklaşım sergilemektedir. Ahlâkî kusurları ise sakındırma yöntemi ile zarar verici, küçük düşürücü, bayağı haller olarak ele almakta, hem dünya hem de ahiret sonuçlarına dikkat çekmektedir. Bu yolla ahlâkî kusurlara karşı bir nefret ve irâdî bir tepki oluşturmaya çalışmaktadır. Aksi halde bu kusurların normalleşeceğini savunmakta ve kusurların yerleşik hale geleceği tehlikesine karşı uyarmaktadır. ${ }^{47}$ Mevlânâ'ya göre doğruluk, verdiği sözü tutmak, konuştuğunda yemin etmeye gerek bırakmayan söz söylemektir. Doğruluk, yalandan ve hileden kaçınmaktır. Şayet bu özelliklerde bir doğruluk inşa edilememişse, Mevlânâ bu durumu, dine vefasızlık olarak görmekte ve kişiyi münafıklık tehlikesi konusunda uyarmaktadır. ${ }^{48}$ Diğer yandan yalanı sözde, hileyi de davranışta doğruluk değerinden uzaklaşıldığının göstergesi olarak kabul etmektedir. Aynı zamanda, bu bakışı ile doğruluğun olmadığı ahlâkî yapıya yerleşecek kötü vasıfların neler olduğuna işaret etmektedir. Mevlânâ'ya göre hile ve yalanın varlığı, uygulanacak eğitimde doğruluk, dürüstlük değerini kazandırma önceliğine duyulan ihtiyaca işaret etmektedir. Zira kişide doğruluk yerleştirilemediği sürece hile ve yalandan korunmak ve kurtulmak pek mümkün değildir.

\footnotetext{
${ }^{44}$ Hüseyin Peker, Din ve Ahlâk Eğitiminde Psikolojik ve Metodik Esaslar, 2. Basım (Samsun: Aksi Seda Matbaası, 1998$), 192$.

${ }^{45}$ Mesnevî, C. VI, 323, b. 4310.

${ }^{46}$ Mesnevî, C. I, 232.

${ }^{47}$ Mesnevî, C. I, 234-235

48 Mesnevî, C. II, 224-227.
} 
Mevlânâ, İslâm ahlâk eğitiminde nefsin eğitimi ile hedeflenen en nihaî değer olan adâletin doğrulukla yakın ilişkisine dikkat çekmektedir. Mevlânâ, doğruluğu ayırıcı kriterleri ve adâlet için doğruluğun gerekliliğini şöyle açıklamaktadır:

Emîr Muaviye dedi ki: "Doğruluktan başka hiçbir şey seni kurtaramaz, adâlet seni doğruluğa davet etmektedir. Doğru söyle de elimden kurtul, hile savaşımın tozunu yatıştıramaz!"

- Şeytan dedi ki: “Ey hayal kuran ve türlü düşüncelere dalan Muaviye! Yalan ile doğruyu nasıl ayırt edersin?"

- Muaviye; “Hz. Peygamber Efendimiz buna dair bir açılama yapmış, kalp için sağlam mihenk taşı vermiştir. Buyurmuştur ki: "Yalan kalplerde şüphe uyandırır; doğru ise insana emniyet ve neşe verir.

- Doğru söz gönlü rahatlatır. Doğru sözler gönül tuzağının taneleridir. Gönül hasta ve ağzının tadı bozulursa, doğru ile yalanın çeşnisini, ayırt edemez. Fakat gönül hastalıktan kurtulmuş olursa, yalanın, doğrunun tadını bilir ve anlar. ${ }^{49}$

Mevlânâ, devamındaki beyitler ile Hz. Âdem'in şeytanın yalan ve hilesi karşısında yaşadığı durumu hikâyelendirmektedir. Burada yalan ve hilenin değerli bir varlık olan insanı ne hale düşürebileceğinin tasvirini şöyle yapmaktadır: "Ey Şeytan, Âdem senin yalanına, işvene kulak astı, sana aldandı ve öldürücü zehri içti. Hz. Âdem buğdayı akrepten ayırt edemedi. Çünkü hevesinin, isteğinin sarhoşu olanın ayırt etme duygusu kalmaz." ${ }^{50}$ Görülmektedir ki Mevlânâ'ya göre doğruluk, ruhu hayal ve yanıltıcı düşünceden temizleme imkânını içermektedir. Zira Mevlânâ, hayal ve düşüncelerden, şüphe veren hallerden kurtulamama halinde doğru sözün gönle girmeyeceğini ve bunun bir hastalık olarak görülebileceğini savunmaktadır. ${ }^{51} \mathrm{Bu}$ durumu o kadar vahim görmektedir ki doğru sözün bile o gönül için illet haline geleceğini ifade etmektedir. Bu hastalığın ise ahmaklığı ortaya çıkaracağına ve artık burada eğitimin sonuçsuz kalacağına vurgu yapmaktadır. Bu kişiye karşı da sükutu tavsiye etmektedir.

Diğer yandan Mevlânâ, ahlâk eğitim kavramlarından olan gönül ile yalan arasında bir bağ kurmaktadır. Mevlânâ, bu yolla yalan söylemenin içsel âlemde nasıl bir etki oluşturacağına dikkat çekmektedir. Zira Mevlânâ'ya göre bu konuda bir bilişe sahip birey, bu duygular ile karşılaştığında onları tanıyacak ve sebeplerinin farkındalığına sahip olabilecektir. Diğer yandan Mevlânâ, gönlün yalan olan söz ve davranışlara karşı ilâhî bir duyarlılığa sahip olduğuna dikkat çekmektedir. "Gönül asla yalan söylemez" diyerek Mevlânâ, bütün yalanlara rağmen gönlün hakikat olanın farkındalığı içinde olduğunu savunmaktadır. Gönül, bu özelliği sebebiyle hem diş âlemde hem de iç âlemde hakikatleri yansıtmanın mücadelesi içine girmektedir. Mevlânâ, gönüldeki bu ilahî yöne rağmen yalan ve hileye düşmeyi, "körün kuyuya düşmesine şaşılmaz; asıll şaşılacak şey, yol gören kişinin düşmesidir" diyerek eleştirmektedir. ${ }^{52}$

Görülmektedir ki Mevlânâ, gönlün hakikatleri yansıttığını, gönlü bulandıran durumların doğruluktan uzaklaşmayla ilişkili olduğunu savunmaktadır. Yalanı inancın ortaya çıkışına engel olarak görmekte, küçük düşürücü sonuçlarına dikkat çekmektedir. Bu yönü ile yalan, ahlâk eğitiminin koruyucu nitelikleri ile sakındırdığı bir kusurdur. Mesnevî, doğruluğa inanç açısından önemli bir değer olması sebebiyle yer verdiği kadar, yalana da sakınılma gerekliliği üzerinden yer ayırmaktadır. Bu yolla doğruluğun kazanımı, yalandan da kaçınma iradesini ortaya çıkarmaya çalışmaktadır. O halde bu kavramların, inançla olan ilişkisi ve insan için iç ve dış âlemdeki sonuçlarına dair bir biliş kazanmadan bu iradenin ortaya çıması mümkün görünmemektedir. Bu sebeple bir değer eğitimi sürecinde bu iradi gücün hedeflenmesi, doğruluk ve yalanın bu güçle ilişkisine dair bir farkındalığın olması gerekir.

\footnotetext{
${ }^{49}$ Mesnevî, C. II, 217, b. 2730-2735.

${ }^{50}$ Mesnevî, C. II, 218, b. 2740.

${ }^{51}$ Mesnevî, C. II, 216, b. 2715.

${ }^{52}$ Mesnevî, C. VI, 210.
} 


\subsection{Hile}

Hile, kişinin beğenmediği şeyden sevdiği şeye geçmesidir. Hile, doğruluktan ayrılan kişinin sözle yalana başvurmasının ardından, davranışlarıyla da yanıltıcı olmasını karşılamaktadır. ${ }^{53}$ Hile, yalanın bir sonucu olarak ortaya çıkmakta ve terbiye sürecini zora sokan alışkanlıkların varlığına işaret etmektedir. Mevlânâ, hikâyelerinde bu kusur ile anılan prototiplere sıklıkla yer vermektedir. Ahlâk eğitiminin doğruluk-dürüstlük değerini kazandırmasının önem ve önceliğini, yalan ve hilesi ile tanınan hikâye kahramanları üzerinden vurgulamaya devam etmektedir. İnsanı hileye sürükleyen unsurlara dikkat çeken Mevlânâ, konuyu insanların, nefsin, şeytanın, eşyanın, dünyanın hileleri üzerinden ele almaktadır. ${ }^{54}$ Mevlânâ, yapılan hilenin dinî ve toplumsal zararlarına Mesnevî'de geniş yer vermektedir. ${ }^{55}$ Hikâyeler ile hilenin sorunlu kişilik yapısına yol açan örneğini vermekte ve bu durumun imanı zedeleyecek, ortadan kaldıracak kadar tehlike içerdiğine dikkat çekmektedir. Kişiyi münafık veya kâfir olarak tanımlamaya yol açacak bu kusurların, eğitim açısından da terbiyenin tesirinin olmadığı kişilik özelliği olarak görmektedir. Mevlânâ'ya göre terbiye sürecinde kişi, bu kusurlara yol açan hal ve davranışlardan korunamadığında iman ortadan kalkmaktadır. Bu da bireysel sağlığın, dinî ve ahlâkî düzenin, toplumsal birliğin bozulması anlamı taşımaktadır. Mevlânâ, bir kişinin hileyle anılıyor olmasını o kişinin kötü ahlâklı insan olması ile aynı görmektedir. ${ }^{56}$ Burada katî bir duruş sergilemekte ve hile konusunda kişinin ahlâkî olarak sakınma ihtiyacına vurgu yapmaktadır. ${ }^{57}$ Mevlânâ, ahlâk eğitiminde yalan ile hileyi ilişkilendirmektedir. Yalan ve hileyi şeytanî vasıflar olarak telakki etmekte ve bu niteliklerin kul olmaya engel olacağını vurgulamaktadır. Bu iki kusurun haseti doğuracağına, besleyeceğine vurgu yapmakta ve bu durumun da ahlâkî bir çöküntü anlamına geldiğini ifade etmektedir. Kurtuluşu ise doğruluk ve dürüstlük değerini kazanmakla mümkün görmektedir. Yaptığ1 eğitimle de kişiyi bu konuda bilinçlendirmeyi istemekte ve bu kusurlardan sakındırmaktadır. Zira yalan ve hilenin bir arada bulunuşluğu, kişi için bu kusurlardan korunmayı zorlaştırmaktadır. Bu kusurlar kişinin iç aleminde büyük yıkıcı etkilere yol açacağı için güven duyulan ve güven veren bir şahsiyetin oluşması mümkün görünmemektedir. Bu da toplumdan kopuş anlamına gelmekte ve kişiliğin oluşumuna engel olmaktadır. Görülmektedir ki Mevlânâ'da bu kusurun öğretiminde iman ile olan ilişkisi, kişide bu kusurun varlığına işaret eden düşünce, duygu ve davranış modellerine ait tanıtıcı bilgilerin öğretimi önem taşımaktadır. Bu kusurun, doğruluk değerinin yokluğu halinde ortaya çıtığı ve tedavisinin doğruluk değerinin kazanımı ile mümkün olacağının bilinmesi, işlevsel bir öğretimin yapıldığı anlamı taşımaktadır. Bu yolla kişi, kendi kendini değerlendirmeye tâbi tutma ve terbiye etme sürecine aktif katılma imkânı bulmaktadır.

\subsection{Kıskançlık-Haset}

Bir başkasının sahip olduğu maddî veya mânevî imkânları kıskanmak, onların kendisine geçmesini istemek şeklinde tanımlanan haset-kıskançlık duygusu doğuştan var olan bir duygudur. ${ }^{58}$ Aynı zamanda haset, kişide kederlenme, kalp yorgunluğu ve azabı gibi kötü sonuçları olan bir erdemsizliktir. ${ }^{59}$ Burada önemli olan, hasetin ortaya çıkaracağı kötülüklerin farkında olunması ve bu duyguda itidal için ilâhî yardımın talep edilmesidir. Çünkü bu duygu kişi üzerinde güçlü etkiler oluşturmaktadır. Kişinin bu duyguyu tanıyor olması, yıkıcı etkilerine karşı kontrol oluşturması beklenmektedir. ${ }^{60}$ Haset, şeytanın azgınlığını temsil eden bir duygudur. Mevlânâ, bu duygu nedeniyle

\footnotetext{
${ }^{53}$ Seyyid Şerif Cürcânî, Kitabü't- Ta'rifât, çev. Arif Erkan (İstanbul: Bahar Yayınları, 1997), 91.

${ }^{54}$ Ayrıntılı içerik için bk. Mesnevî, C. VI, 57; C. I, 163; C. IV, 135; C. VI, 21-22; C. III, 54-55; C. V, 107.

${ }^{55}$ Mesnevî, C. II, 224-230.

${ }^{56}$ Mesnevî, C. IV, 189.

${ }^{57}$ Mesnevî, C. V, 51-52.

${ }^{58}$ Cürcânî, 87.

${ }^{59}$ Bedreddin İbn Cemâa El-Kinânî, İslâmi Gelenekte Ĕ̆̆itim Ahlâkı, çev. M. Şevki Aydın, 2. Basım (Ankara: TDV Yayınları, 2012), 83.

${ }^{60}$ Mesnevî, C. VI, 62, b. 695.
} 
saadetten mahrum kalındığını belirtmektedir. Mevlânâ'ya göre Hakk yolunda en zor ve tehlikeli geçit, haset duygusudur. Zira şeytan bu duygu sebebiyle Âdem'e secde etmeye utanmıştır. Haset, ruh evini karartan duygulardandır. Bu sebeple Mevlânâ, "Evimi temizleyin"61 ayetindeki emrin işaret ettiği duyguyu haset olarak anlamaktadır. ${ }^{62}$

Mevlânâ'ya göre haset, kötülüklerin oluşmasına sebebiyet veren bir duygu olmasının yanında iyilikleri de yok eden bir özellik taşımaktadır. Bu sebeple Mevlânâ'da sevgi, hoşgörü, cömertlik, şükür, kanaat gibi birçok değer haset duygusunun insana hâkim oluşuna engel olmaktadır. Zira bu değerler kıskançlığı dengeleyen, kişiyi kıskançlık duygusunun etkisinden kurtaran değerlerdir. Bu özellikleri üzerinden bakıldığında Mevlânâ'ya göre haset, fıtrî olması, kötüye yöneltmesi ve iyilikleri yok etmesiyle kötü ahlâkı ortaya çıarmada belirleyici unsurlardan biridir. Bu sebeple Kur'ân'da bu duyguya, duyguyu kontrol etmenin zorluğuna ve ilâhî yardımın gerekliliğine dikkat çekilmektedir. Mevlânâ, bu sürece ve haset duygusunun kişinin iç ve dış dünyasında oluşturacağı yıkıcı etkiye vurgu yapmaktadır. Mevlânâ, haseti kişiyi bireysel gelişimden alıkoyan bir duygu olarak anlamaktadır. Başkaları ile meşgul olan zihnin ve kalbin kişide bir hastalık olduğunu, bu kişinin sürekli olarak hesap ve arzular içinde kıvranacağını düşünmektedir.63 Böyle bir durum Mevlânâ'da kişinin gelişimi ve değişimi açısından enerji kaybı olarak görülmektedir. Bu kişi, iç huzursuzluğun pençesine kapılmış kişidir.

Mevlânâ, haset duygusunu mânevî gelişime engel olması yönüyle eğitimine konu etmektedir. Haset duygusunu, insanlığın başlangıcına dayandırmakta ve şeytana has bir vasıf olarak görmektedir. ${ }^{64} \mathrm{Bu}$ sebeple Mevlânâ, şeytanın Âdem'e secde etmemesi sebebiyle içine düştüğü duruma vurgu yapmakta, hasedin ebedî saadete engel olacağına dikkat çekmektedir. Mevlânâ, haset duygusuna karşı ihtiyatlı davranmanın ve bu duyguya kapılmış kişilerin yaşadıklarından ders almanın önemine vurgu yapmakta ve burada ihtiyatı ve ders almayı öğreten bir eğitim örneği ortaya koymaktadır. Zira iç dünyayı yakıp yıkan haset, bireysel ve toplumsal ilişkilerde büyük hata ve sorunlara yol açmakta, insanî ilişkilere büyük zarar vermektedir. O halde haset duygusuna karşı sistematik, dinamik, koruyucu (önleyici) bir eğitim süreci değer eğitiminin önemli bir kısmın oluşturmaktadır denilebilir. Sistematik olarak kişi bu duygu ve bu duygunun özellikleri gibi konulara ait bir bilgilenme sürecine girmelidir. Bu duygunun sürekli kontrol altında tutulması gereken bir duygu olduğunun bilinci ile hareket etmeyi sağlayan güçlü bir irade oluşturulmalı ve bu duygunun yıkıcı alanlarına girmekten korunma ihtiyacının önemi gibi konulara ait ayet ve hadisler ışığında ikna edici bir eğitimin uygulanması gerekir.

\section{Sonuç}

Değer kazanımı, çok yönlü bir eğitim gerektirmektedir. İnsana ait her unsur ve her olgu bu eğitimin bir yönünü veya örneğini oluşturur. Bu kazanım insanın kendisiyle, diğer insanlarla, canlı veya cansızlarla, içinde yaşadığı evrenle ilişkisinde belirleyici bir rol oynamaktadır. O halde değer kazanımı temelli yapılacak bir eğitimin bütün bu ilişki alanlarına ait konu ve durumları içermesi, işlevsel ve aktif bir süreçle anlatımının yapılması gereklidir. Zira böyle bir eğitimden kötüye karşı sakındırıcı, iyiye teşvik edici, rol modeller kazandıracak somutlukta, duyuşsal anlamda bir değer, bilişsel anlamda bir kültür, davranışsal anlamda bir tercih oluşturacak güce sahip olması beklenir. Diğer yandan bu amaçla yapılan faaliyetlerin daha etkin uygulama örneklerine ihtiyaç vardır. Örneğin insan ait bir olgu, durum veya duygunun bir hikâye-temsil örneği üzerinden anlatımını yapmak; içeriğin, karakterlerin, duyguların, düşüncelerin, mevcut bilgilerin, davranış modellerinin

\footnotetext{
${ }^{61}$ Bakara, 2/125

${ }^{62}$ Mesnevî, C. I, 51, b. 430 vd.

${ }^{63}$ Mesnevî, C.V, 106.

${ }^{64}$ Mesnevî, C. II, 126.
} 
değerlendirmeye tâbi tutulmasına zemin oluşturan bir eğitim uygulaması anlamına gelmektedir. Böyle bir eğitim ise bilişsel, duyuşsal ve davranışsal bütünlüğe sahip bir kazanımı ve değişimi mümkün kılmaktadır. Ancak bu şekilde kişinin doğru ve yanlışları öğrendiği, kendi dünyasında bu durumlara ait karşılıkları eleştirmeye, değerlendirmeye tâbi tuttuğu, aktif katılımın olduğu ve işlevsel şemaların kazanıldığı, kusurlara karşı bir sakınma ve iyiyi yapmaya dair bir teşvikin oluşturulduğu bir eğitim örneği ortaya konulmuş olacaktır. Nitekim böyle özellikleri barındırması anlamında Mevlânâ'nın Mesnevî eseri, önemli bir değer kazanımı imkânı sunması sebebiyle bu makalede temel kaynak olarak kullanılmıştır. Bu makale konusu çerçevesinde yapılan araştırmada Mevlânâ'nın birçok ahlâkî değer ve kusura yer verdiği ve bunların eğitiminde sıklıkla;

- $\quad$ ahlâkî değer ve kusurların teorik zemininden ziyade pratik alandaki etkilerine dair tahliller yaptığı ve farklı hikâyelerle tekrar tekrar bu kavramları gündemine aldığı,

- $\quad$ ahlâkî değerlerin işlenişinde zıt kutupların neler olduğuna dair ipuçları verdiği, arzulanması gerekenin ne olduğuna ve kaçınılması gerekenin ne olduğuna dair bütüncül bir bakış açısı oluşturmaya çalıştığı,

- ahlâkî değer ve kusurların kişi üzerindeki etkinliğinin arka planını, yaratıcı tasavvuru ve ahiret inancının doğru ve tam olması ile ilişkilendirdiği,

- metodik olarak şiir ve hikâye anlatımı, sorular üzerinden cevaplar arama, rol modeller sunma, soyut olay ve konuları somutlaştırma, tekrar, ayet ve hadislerle deliller sunma, örnek olaylar üzerinde tartışma ve beyin fırtınası veya tefekkür etme gibi yöntemleri sık sık kullandığı,

- ahlâkî değerlerin ve kusurların öncelikli olarak inaçla ilişkisini, duygular, düşünceler ve davranışlar üzerindeki etkinliğini ve modellerini örneklediği,

- ahlâkî değer ve kusurların eğitiminde teşvik etme ve sakındırma üzerinde fayda ve zararlarına dair bir öğretim yaptığı,

- $\quad$ ahlâkî değerlerin ve kusurların Kur'ân ve Sünnette öne çıkan yönlerine ve özelliklerine atıflar yaptığı ve deliller sunduğu,

- $\quad$ ahlâkî değerler ve kusurlar arasındaki ilişkiye vurgu yaptığı, hangi değerin hangi kusurla nasıl bir ilişkisi olduğuna dair bir öğrenme gerçekleştirdiği,

- ahlâkî değerleri ve kusurları, dünyaya ve ahirete bakan yönleri üzerinden bir değerlendirmeye tâbi tuttuğu ve insan için bu sonuçların önemini açıklayarak öğütler verdiği,

- ahlâkî değerlerin ve kusurların bireysel ve toplumsal yaşama bakan yönlerine ve bu yönlerin insan için önemine dikkat çektiği,

- ahlâkî değerlere ve kusurlara ait konu, olay ve olguları somutlaştırarak, değer ve kusura ait özellikleri taşıyan rol modeller üzerinde hikâyeler anlattığı,

- ahlâkî değerlerin ve kusurların iman/inançla ilişkisi üzerinden bir değerlendirmeye tâbi tuttuğu, ahlâkî değerleri ve kusurları İslâm ahlâk eğitimindeki anlamlarına, işlevlerine bağlı ele aldığ 1 ,

- insanın olumlu yönden değişim ve gelişim ihtiyacına ve bu ihtiyaca cevap vermede değerlerin imkân, kusurların engel oluşuna vurgu yaptığı,

- psikolojik unsurlar olarak kişinin güçlü bir inanç sahibi olması, nasihat almaya hazırbulunuşluğu, aklını kullanma yeteneği ve bilgi düzeyi, bu eğitim konusunda ısrarcı ve ciddiyete sahibi olması ve hayatın içinde muhtemel konu ve örnekler üzerinden öğrenme, doğru tercihte bulunma, tedbir ve öğüt alabilmede gerekli bilişsel-duyuşsal olgunluğa sahip olma ve farklılıkları dikkate alma gibi kriterlere yer verdiği bir eğitim örneği ortaya koyduğu görülmüştür.

\section{Öneriler}

Değer eğitimi bağlamında yapılacak bir eğitim faaliyetinde Mevlânâ'nın eğitim örneğinden yola çıarak;

$>$ Değer kazanımını anlamlı ve mümkün kılan bilgileri aktarma, muhtemel soru ve sorunları örnekleyen olayların üzerinde geniş tahlillere yer verme, 
> Yerinde özel ve özet bilgi aktarımı yaparak çoklu öğrenmeyi mümkün ve etkili kılma, pekiştirme,

> Kuvvetli içsel unsurlar oluşturma (tam ve sağlam bir inanç gibi) ve bu unsurlar bağlamında değer ve kusurların etki alanlarını ortaya koyma,

> Bireysel farklılıkları göz önünde bulundurarak farklı metotlardan yararlanma ve farklı hikâye örgüleri ile değerleri ve kusurları hikâye etme,

> Kişinin yaşamı içinde tecrübelediği konu, düşünce veya duygulara yer vererek bunları değerlendirebileceği bir eleştirel bakış kazandırma,

> Değerlerin önemi ve kusurların yıkıcı etkilerine dair devamlı bir bilgi aktarımı yapma,

$>$ Bu eğitimin ciddiyet içeren bir eğitim olduğunun farkındalığını oluşturma, sık sık tekrarlara yer verme, ayetler ve hadislerle deliller sunma,

> Hikâyelerde gelinen noktayı müzakere etme ve kavramla ilgili farklı cihetleri münazara örneklerine yer vererek resmetme,

> Problem çözme gibi didaktik metodları kullanma, değerler veya kusurların ortaya çıkışında belirleyici olan bireysel veya toplumsal unsurları tanitma,

> Davranış, düşünce ve duygu sorunlarına yol açan sebeplere ait doğru tespitlerin ve sorunlara uygun çözüm ortaya koyacak doğru tedavilerin neler olduğuna dair bilgilendirmenin yapılması gibi özellikleri taşıyan bir eğitim örneği ortaya koymanın bu tecrübeden yararlanma imkânı oluşturacağı gibi öneriler sunmak mümkündür.

\section{Kaynakça}

Akseki, A. Hamdi. Ahlâk Dersleri. Ankara: DİB Yayınları, 2016.

Arabî, İbnü'l Muhyiddin. Fusûsü'l Hikem. çev. Ekrem Demirli. İstanbul: Kabalcı Yayınları, 1999.

Bayraklı, Bayraktar. Kur'ân'da Değişim, Gelişim ve Kalite Kavramları. İstanbul: İfav Yayınları, 1999.

Can, Şefik. Mesnevî Tercümesi. İstanbul: Ötüken Yayınları, 2016.

Cevizci, Ahmet. Ĕ̆itim Sözlüğü. İstanbul: Say Yayınları, 2010.

Cürcânî, Seyyid Şerif. Kitabü't- Ta'rifât. çev. Arif. Erkan. İstanbul: Bahar Yayınları, 1997

Çağrıcı, Mustafa. "Müsamaha". Diyanet Vakfı İslâm Ansiklopedisi. İstanbul: Türkiye Diyanet Vakfı Yayınları, 2009.

Çakmaklı, Kemal. Koruyucu Ruh Sağ lı̆̆ı. İstanbul: Seha Yayınları, 1997.

Çelebi, Esin - Şimşekler, Nuri. Mevlânâ'dan Mevlaya Ulaşanlar. Konya: Bahçıvanlar Matbaa, 2012.

Çınar, Aliye. Erdemler Felsefesi ve Psikolojisi. Bursa: Emin Yayınları, 2013.

El-Askerî, Ebu Halil. Arap Dilinde ve Kur'ân'da Farklar Sözlüğ̈̈̈. İstanbul: İşaret Yayınları, 2. Basım, 2013.

es-Sicistânî, Ebu.Davud. Sünen. çev. H. K. Necati Yenial. İstanbul: Şamil Yayınları, 2011

Hanbel, Salih bin Ahmet. Müsned. çev. Z. Y. Hüseyin Yıldız. İstanbul: Ocak Yayınları, 2013.

Hökelekli, Hayati. Değerler Psikolojisi ve Eğitim. İstanbul: Timaş Yayınları, 2011.

İhvân'ı Safâ. Resâilü İhvâni's Safâ ve Hullâni'l Vefâ. 4.Cilt, Beyrut: Daru Sadır, 1974.

İnan, Y. Ziya. İslâm Ahlâkının İçeriği. 1. Cilt , İstanbul: Yaylacık Yayınları, 1992.

Kinani, Bedreddin İbn Cemaa. İslâmi Gelenekte Eğitim Ahlâkı. çev. M. Şevki Aydın, Ankara: TDV Yayınları, 2012.

Koç, Ahmet. İhvân-ı Safầnın Ĕ̆itim Felsefesi. İstanbul: İfav Yayınları, 1999

Nicholson, Reynold Alleyne. The Matnawi of Jalaluddin Rûmî IEII. Lahore: İslamic Book Service, 1989.

Peker, Hüseyin. Din ve Ahlâk Ĕ̆itiminde Psikolojik ve Metodik Esaslar. Samsun: Aksi seda Yayınları, 2. Basım, 1998. 